\title{
Limitations of Local Community to Participate in Community-Based Tourism (CBT): A Study on Sylhet
}

\author{
Shelamony Hafsa \\ Lecturer, Department of International Tourism and Hospitality Management, School of Business, Primeasia \\ University, Dhaka, Bangladesh
}

\begin{abstract}
Community-Based Tourism is one of the emerging ideas of ensuring community's participation in tourism developments as a contrivance of sustainability. And Sylhet is one of the naturally blessed areas in Bangladesh with tea-garden, waterfalls, tropical forests, community people and religious view. But Community people have lack interest on the participation of tourism activities due to different reasons. The main objective of this article is to identify the major limitations to community's participation in Community-Based-Tourism in Sylhet region. Both qualitative and quantitative analysis is done for identifying those limitations. Regression analysis as well as other measurements was used to analyze the opinions/factors found from questionnaire survey. This paper identifies some limitations which are considered as the major reasons of community people's poor participation such as poor communication skill and expertise of community people, low benefit sharing opportunity, poor decision making opportunity of them, poor knowledge, insufficient marketing and financial supports . It also presents necessary recommendations based on the findings of the analysis on how these limitations could be removed and ensures more community participation in tourism development of that region.
\end{abstract}

Keywords: Community participation,tourism and Community-Based Tourism (CBT), major limitations.

DOI: $10.7176 / \mathrm{JTHS} / 45-03$

Publication date: December $31^{\text {st }} 2019$

\section{Introduction:}

Travel and tourism is one of the fastest growing industries (Dwyer and Spurr, 2010) and day by day, it is contributing more and more to the world economy (WTTC, 2016). In the recent years, this emerging industry has started to contribute significantly to the national economy of Bangladesh (WTTC, 2016). Community-Based Tourism is a form of tourism which emphasis on the involvement of the host community in every stage of tourism development process in order to make it more sustainable. It can be regarded as a tool for community development, cultural, heritage and natural resource conservation of that community. Community Based Tourism gives visitors a unique opportunity to meet local people, experience and learn about local culture, livelihoods and relationships between people and environment. It is designed to support social and environmental work, build local skills and distribute benefits broadly. Now-a-days, Tourism experts are giving more concentration on Community Based Tourism because they believe that involving the community can make tourism sustainable. Although in general many researchers have a common opinion that community participation is an important tool to achieve sustainable tourism development at a destination and it is also believed that greater the degree of community participation is, the better development or planning will be. Sylhet regions have rich natural, cultural and religious attractions which work like more valuable ingredients to promote tourism industry in Bangladesh. Different ethnic community people stay there who have attractive cultural and historical background. Their diversified cultural elements could be considered as more attractive tourism products. It will provide the authentic experience to tourists and introduce them with the host people. Community-Based Tourism could be the more effective model for this region to ensure the conservation and development of the area and community. So it is very important to include host communities in the process of tourism development in a more positive way to get the best support from them. But community people are unable to participate because most of the cases they have poor decision making opportunity and profits earned from tourism industry aren't properly distributed among the beneficiary groups. Community people also sometimes can't directly involve due to poor financial support to run a business and poor specialized skill. Even sometimes they aren't properly informed about community's participation and their benefits. Thus they reluctant to involve with tourism related activities.

\section{Literature review:}

Tourism is one of the most profitable sectors in Bangladesh (Elena et at, 2012).It creates job opportunities for the local people as well as contributes in the national GDP of any particular country. It supports the socio-economic development of rural areas by diversifying rural economies, providing linkages between different economic sectors, generating employment opportunities and increasing the value of local culture and environment (Sharpley and Sharpley, 1997; Telfer, 2002). As Ashley and Roe (1998) noted that "Tourism can bring an array of advantages both for rural communities and for developing economics".

Community-Based Tourism is a tool of sustainable tourism that is run and managed by the community and 
local people are considered as the decision makers (Khanal \& Babar 2007). Community-Based Tourism is premised on the inclusion of local people in the development of the industry. In fact, its characteristics include local control of development, community involvement in planning, equitable flow of benefits, and incorporation of resident values (Tosun 2006; Blackstock 2005; Reid 2003; Hall 1996; Pearce 1992; Haywood 1988; Murphy 1985). Now-a-days more emphasis is given on the improvement of host community through the tourism activities. It will be possible though the stakeholder's co-operation and participation in tourism development process (Dodds, 2007; Simpson, 2008). Community-Based Tourism has the potentials to address all aspects of sustainability: economy, society and environment (APEC Tourism Working Group and STCRC, 2010) through giving more emphasis on the participation and development of local community in tourism activities than other forms of tourism. Local community need to participate in every stage of the planning and development process in tourism (Blackstock, 2005; Johnson, 2010; Murphy and Murphy, 2004). And community people will be more interested if they could be assured that tourism won't negatively affect the existing business and activities as well as the environment (Murphy and Murphy 2004) rather it could be beneficial for the local people by ensuring proper power and resource distribution among them. This idea of involving local people in all tourism activities and decision making will help to increase incomes, employment opportunities, education level and interest of local communities on tourism and entrepreneurship (Timothy, 1999).

Local communities have to face (directly or indirectly) both negative and positive impacts of tourism activities. That's why their participation in tourism development is essential for community's betterment as well as tourism industry's flourishment. They have deep knowledge about that place, local products, accessibility, rituals, and cultural values. So, they can plan better for Community-Based Tourism development than outsiders. Local communities can be recognized as the crucial resource and essential elements in every aspect of tourism activities. Sometimes the participation of local communities is considered as the fundamental stair in the success of sustainable tourism (C.Tosun and Timothy, 2003). But in practical life, communities aren't considered as equal partner in every step of tourism development especially in decision-making process.

Lack of awareness of local community, limited capacity of local people (e.g; time, expertise and financial resource), poor resource management capability, power disparities are some of the barriers in community's participation in tourism activities (C Tosun, 2000). However, the poor and insolvent families have low interest in the participation although they can earn their living by involving in tourism activities (D.Timothy, 1999). The main challenge for them is tourism activities creates seasonal employment opportunities and they have to spend more time and energy but they have limited financial support as well as poor skill, inadequate facilities that they can offer to tourists (Pearce, 1992).Imbalanced distribution of power in the stages of planning, operational and structural levels is another hinders of community's participation (R.Nunkoo,H.Ramkisson, 2010). This imbalanced distribution will also deprived the less power owner to enjoy the benefits that gained from tourism activities. Another constraints is lack of awareness of local community about the significance of their participation (Johnson, 2010) which often occurred due to low level of education and lack of information about tourism development and its beneficial sites. Each of these barriers is interrelated to each other which need to be removed for ensuring the active participation of local community in tourism activities.

\section{Objectives of the study:}

Primary objective of this study is to identify the major drawbacks of local community's to participate in Community-Based-Tourism (CBT). Secondary objectives of this study are:

- Recommend the ways to remove those identified drawbacks of local community's participation in tourism and Community-Based Tourism related activities.

- To access local community's interest and opinion regarding community-Based Tourism and their participation in tourism related activities.

- Recommend the ways to develop Community-Based Tourism in Sylhet ensuring local community's participation in the development activities as well as protecting natural, cultural, environmental heritage and assets of this destination.

\section{Methodology of the study}

This research is done based on the descriptive method. There are three main types of descriptive methods: observational methods, case-study methods and survey methods. (Jackson, S.L. (2009)).With the observational method (sometimes referred to as field observation) animal and human behavior is closely observed. For conducting research field observation method is used. Before conducting the research, a field visit was completed at Sylhet and tried to observe the culture, traditions, behavior, perceptions and eagerness of different community -especially Manipuri community and their interest in involving tourism activities and tried to identify the major hinders of their participation. Both qualitative and quantitative analysis is done and survey method was used to supplement the findings of the qualitative approach. Based on the literature review and findings from the initial interview and observation 10 variables were finally identified and survey questionnaire was made based on those 
variables. Survey questionnaire was divided into two parts: sociodemographic parts and respondent's opinion on the limits of community participation on Community-Based Tourism development. The instructions of five point liker scale were used while preparing and analyzing the questionnaire survey. Necessary data were collected from both primary and secondary data sources. Interviews of different stakeholders, field observation, questionnaire, expert's opinion were considered as primary data sources and different articles, journals, books, newspapers, and other papers published by government and different national and international organizations were considered as secondary data sources for this study. Both convenience and judgmental (non-probabilistic sampling technique) techniques were used for sample selection and sample size was selected based on the research's personal knowledge as well as based on a focus group discussion with some tourism experts and academicians. Total sample size was 100 respondents who were divided into four groups-community people, tourists, other stakeholders and experts. As Community-Based Tourism isn't well-established in this area, researcher wants to gather the unbiased and core opinion regarding the drawbacks of community people's participation in Community-Based Tourism development process.

Sylhet as a tourism and community-based tourism destination:

Sylhet region is one of the attractive destinations located in the north-eastern part of Bangladesh which is famous for its tea garden, tropical forests, natural lakes, natural waterfalls, tribal communities, natural hill tracts and religious monuments. Srimangal, a part of Sylhet region is known as the tea capital of Bangladesh. This region could be flourished as tourism city of Bangladesh because this city is blessed with so many natural, cultural, historical, archeological, religious and man-made resources. The most prominent tourist spots in Sylhet regions are-Madhabkunda waterfalls, Lawacherra national park(The largest rain forest in Asia), Jaflong, Surma river, Kusiara river, hills of Moulovibazar, tea gardens of Srimongal, Hobigong and Sylhet, lifestyle, cultures and traditions of tribal community specially Manipuri and khasia community. The tribes have different lifestyle, enriched culture, colorful occupations and long history. Most of the peoples of Manipuri community stay at lower part of Moulovibazar. According to the survey, there are 15,309 Manipuri people living in Kamolgonj Thana in Moulovibazar district. Alongside those area they live in some other thanas of Sylhet-Amborkhana, Nayabazar, Shibgonj, Goaipara., Kewapara, Sagordighirpar, Baghbari, Lala dighir par ,Lamabazar,Doxingach,Rajbari,Noyabazar and other areas. They have different tribal products (shawls, handicrafts, tribal dresses, cultural and historical products) which could be added new dimension in community based tourism. Here,local communities have interest on tourism but they aren't connected with it due to some limitations. If local community can be involved in tourism activities then they will be economically, socially benefited and tourists will get diversified tourism products and better services.

\section{Limitations of sylhet region's local community to participate in community based tourism:}

Each community has some distinct characteristics and they face different barriers in Community-Based Tourism development. There are some persistent barriers that arise in Community-Based Tourism development in Bangladesh; these include poor awareness of people, lack of interest, inadequate resources, inadequate infrastructure and poor market access. Inadequate resources are associated with initial funding sources and opportunities for training to develop skills, knowledge and expertise related to tourism (Graci, 2008).

Lack of funding is another crucial problem in tourism development which discourages local community to participate in tourism activities. Insufficient funding sometimes deprived them from gaining different training opportunities (Choi and Sirakaya 2005). And community people will have poor management and administrative ability due to poor training opportunities. It will also discourage community to participate in tourism development 
process.

Insufficient infrastructural facilities could be considered as another barrier that often faced by rural community (Graci, 2008). Proper infrastructural facilities are essential for ensuring safety and security as well as for providing a pleasant experience to tourists without which tourists will be dissatisfied and demotivated to travel that place.

Due to lack of education and training, community have poor communication power and persuading ability which have negative impact on community's involvement in tourism development process. The World Wildlife Fund (WWF,2001) studied on why many Community-Based Tourism projects were failed in the previous times. They found insufficient of number of visitors are the major reasons of those failure which generally occurred due to poor knowledge of communities, misdirected marketing and poor participation of co Community-Based Tourism development process. Another barrier that can be considered is the poor ability of community to participate, manage and control of tourism activities (Tosun,2000) and poor participation in decision-making steps which is the bone of sustainable Community-Based Tourism project. Strong community support and participation is essential for ensuring the success of tourist destination. While community support and participate in tourism development process, it will return them beneficiaries both economically, socially as well as environmentally (Tosun, 2000). Some other major barriers are-

- Centralization of Power: Administrative power, financial power, planning and others are generally centralized. Government and central authority (organizations at national level) influence the planning as well as plan implementing process. Local community has little or no influence in planning process although they have more practical knowledge on that place. Due to centralization of power, local community feel that they aren't the part of ownership and they are indirectly demotivated to participate in community based tourism. If we look at some developing countries like India, Thailand, Mexico, and Turkey, we can find that they have strong central government who practicing administrative guidance on local government.

- Lack of co-ordination: Tourism industry can't be run in isolation because it serves combined packages of different services (accessibility, accommodation, food and beverage, amenities, safety and security and some other services). So proper co-ordination of different organizations and units like hotel, motel, travel agencies, local experts, local businessman, local authority, national authority, local police, and tourism experts is obligatory for making community based tourism successful.

o Lack of information: Tourism and community based tourism related data aren't properly collected and maintained in Sylhet region. Whether collected, it can't properly disseminate among the locals. Most of the cases, decision maker take decision from their own point of view without circulating information and collecting information from locals. Thus, communication gap exists among the locals and decision-makers. Decision makers have poor interaction with locals and their socio-environmental structure which indirectly demotivated locals to participate in community based tourism related activities.

- Lack of expertise: Tourism industry is basically considered as service industry where skilled peoples are required to satisfy the guest. In Sylhet region, local people have poor training opportunity and additional expertise on tourism related activities which discourage them to participate in community based tourism.

- Lack of financial supports: Financial supports are crucial for executing any plan. And proper financial distribution is needed for the development of tourism elements. But most of the cases local people have poor investment on tourism industry because they have poor financial backup and higher authority just ignored them to offer the opportunity of investment.

- Insufficient marketing: Due to poor marketing, tourists aren't aware about local community of that region and community's products. Thus tourist felt poor interest on them and local communities also dishearten to invest on community based tourism.

\section{Quantitative analysis and findings:}

Data are collected from 100 respondents for this study. Among them 50 were community people, 25 were experts and stakeholders and other 25 were tourists. They provide the real scenario of that place and the needs of Community Based Tourism (CBT) and tried to identify the major drawbacks of poor participation of community people in tourism. This research study is a quantitative analysis (using SPSS software) to identify those limitations of community to participate in tourism. Here, $55 \%$ of the total respondents were male and others $(45 \%)$ were female. $12 \%$ were under 20 years old, $35 \%$ were between 21 to $30,40 \%$ were between 31 to $40,8 \%$ were 41 to 50 and $5 \%$ were above 50 years old. $42 \%$ respondents were service holders, $16 \%$ were engaged in Business activities, $32 \%$ students, $1 \%$ involved in agriculture and rest 9\% involved with other tasks. And the average reliability of the data set is above $68 \%$ which indicates that data are reliable for the research.

Table 1 shows the descriptive statistics of 10 selected variables. Descriptive statistics shows the number of respondents, maximum value, minimum value, mean, standard deviations. Here, the opinions of maximum respondents are between agreed to strongly agree with the statement and some other belongs to the neutral to agree conditions. 
Table 1: Descriptive statistics of all selected variables

\begin{tabular}{|l|c|c|c|c|c|}
\hline & N & Minimum & Maximum & Mean & $\begin{array}{c}\text { Standard } \\
\text { deviation }\end{array}$ \\
\hline Poor decision making opportunity & 100 & 2 & 5 & 4.05 & 0.642 \\
Lack of safety and security & 100 & 3 & 5 & 4.41 & 0.570 \\
Poor financial and other benefit sharing & 100 & 3 & 5 & 4.32 & 0.601 \\
Lack of funding & 100 & 3 & 5 & 4.35 & 0.609 \\
Poor participation in planning Insufficient & 100 & 3 & 5 & 4.70 & 0.461 \\
marketing & 100 & 4 & 5 & 3.75 & 0.702 \\
Negative perception & 100 & 3 & 5 & 3.72 & 0.726 \\
Poor co-ordination among stakeholders & 100 & 2 & 5 & 2.92 & 0.918 \\
Poor resource management capability & 100 & 3 & 5 & 3.85 & 0.857 \\
Poor knowledge and communication skill & 100 & 1 & 5 & 4.42 & 0.554 \\
Valid N (list wise) & 100 & & & & \\
\hline
\end{tabular}

Sources: SPSS output of primary data

This table shows that the maximum average values of all variables is 5 and mean value of poor decision making opportunity is 4.05 where standard deviation is 0.642 Alongside this other variables also shows standard deviation below 1 .

Table 2: Results found from Model summary

\begin{tabular}{|c|c|c|c|c|c|c|c|c|c|}
\hline Model & $\mathbf{R}$ & \multirow{2}{*}{$\begin{array}{c}\mathbf{R} \\
\text { square }\end{array}$} & $\begin{array}{c}\text { Adjusted R } \\
\text { square }\end{array}$ & $\begin{array}{l}\text { Std. error of } \\
\text { the estimate }\end{array}$ & $\begin{array}{c}\text { R square } \\
\text { change }\end{array}$ & $\begin{array}{c}\text { F } \\
\text { change }\end{array}$ & Df1 & Df2 & $\begin{array}{c}\text { Sig. F } \\
\text { change }\end{array}$ \\
\hline 1 & .527 & .257 & .124 & .547 & .131 & 0.931 & 15 & 84 & .030 \\
\hline
\end{tabular}

$$
\text { Source: SPSS output of primary data }
$$

Here, the value of $\mathrm{R}$ is .527 that shows that moderate level of relationships exists between the dependent and independent variables. And value of $\mathrm{R}$ square is .257 . The value of "sig" is .030 which is below 0.050 at the significant level of $95 \%$.

Table 3: Results from ANOVA

\begin{tabular}{|l|l|l|l|l|l|}
\hline Model & Sum of squares & Df & Mean square & F & Sig \\
\hline Regression & 10.659 & 15 & .057 & 0.931 & .030 \\
Residual & 25.051 & 84 & .291 & & \\
Total & 35.71 & 99 & & & \\
\hline
\end{tabular}

Source: SPSS output of primary data

ANOVA table shows that the value of $\mathrm{F}$ is 0.931 and the value of "sig" is .030 which is more than .005 but less than .050 . So, the model will fit at $95 \%$ significant level.

Table 4: Results from Coefficient analysis

\begin{tabular}{|l|l|l|l|l|l|}
\hline \multirow{2}{*}{ Model } & \multicolumn{2}{|l|}{$\begin{array}{l}\text { Unstandardized } \\
\text { coefficients }\end{array}$} & $\begin{array}{l}\text { Standardized } \\
\text { coefficients }\end{array}$ & T \\
\cline { 2 - 5 } & B & Std. Error & Beta & \\
\hline (Constant) & 2.341 & 1.230 & & 1.904 & .060 \\
Poor decision making opportunity & .281 & .104 & .309 & 2.704 & .004 \\
Lack of safety and security & -.097 & .107 & -.095 & -.908 & .366 \\
Poor financial and other benefit sharing & & & & \\
with community & -.010 & .109 & -.011 & 2.095 & .003 \\
Lack of funding & -.089 & .099 & -.093 & -.898 & .126 \\
Poor participation in planning & .384 & .131 & .303 & 2.922 & .004 \\
Insufficient Marketing & -.180 & .092 & -.216 & -1.960 & .053 \\
Negative perception & .045 & .083 & .056 & .542 & .051 \\
Poor co-ordination among stakeholders & .050 & .073 & .078 & .678 & .500 \\
Poor resource management capability & .043 & .074 & .064 & .586 & .559 \\
Poor knowledge and communication skill & .052 & .108 & .049 & 2.477 & .003 \\
\hline
\end{tabular}

$$
\text { Source: SPSS output of primary data }
$$

From this table, it can be said that value of variables - Poor financial and other benefit sharing with community (.003),poor knowledge and communication skill(.003 are most significant at .003 levels. Then the value of poor decision making opportunities and poor participation in planning (.004) are more significant at .004. Here, the value of beta (B) shows that every unit change of independent variable cause the change of a certain portion of dependent variable. Above Coefficient table shows that independent variables-poor decision making opportunity (.004), Poor financial and other benefit sharing with community (.003), poor participation in planning (.004), poor knowledge 
and communication skill(.003) have a strong (significant at .005 level) relationship with dependent variable limitations of community people's participation in Community Based Tourism.

According to the coefficient table, it can be said that these are major barriers behind the participation of community people in tourism. If these barriers can be removed, Community participation will increase and Community Based Tourism (CBT) will become successful.

\section{Recommendations:}

Sylhet has great potential to be flourished as community-based tourism destination in Bangladesh. Local communities also agree with this but they felt different major problems. Some recommendations are enclosed here which will help to remove the barriers of community people to participate in tourism activities-

I. Rising of awareness and capacity building on community level are the first issues which predetermine the further success of establishment of a Community Based Tourism (CBT) framework in Sylhet. Because for the conservation of all types of resources, maintaining carrying capacity is must in any destination.

II. Local communities need to offer the opportunity of involving in tourism planning in their communities on highest possible level and should provide decision making opportunity when it comes to Community Based Tourism (CBT) development project in their community.

III. Awareness among the community should increase for changing their perception on tourism. If they become aware and knowledgeable on tourism, their interest on Community Based Tourism (CBT) will increase.

IV. Profit and other benefits should properly distribute among all stakeholders of Community Based Tourism (CBT) and it will help to motivate community people on Community Based Tourism (CBT).

V. Government, NGOs and Bangladesh Tourism Board (BTB), Bangladesh Parjatan Corporation (BPC) and all other stakeholders need to take necessary steps to involve local community in community-based tourism for making the Community Based Tourism (CBT) successful in Sylhet. They also have to offer funds for boosting communities participate in tourism related business. As well as enough financial supports should provide all stakeholders to make the Community Based Tourism (CBT) program successful in this community.

VI. Training and workshop facilities need to develop in Sylhet region for the skill development of the community. It will also help to enriched community's knowledge on tourism and tourist and to develop their communication and others required professional skills.

VII. Local market needs to create for selling indigenous community's products and services. It will help to maintain the economic sustainability of the community and encourage them to participate in community-based tourism.

VIII. Ensuring job security of the locals. They have perception that tourism is a seasonal business. If they get involved with it then, they have to free during off-season. But now tourists prefer to travel almost all seasons of a year and community have the opportunity to sell their own products to tourists and other people's and render service though participation.

IX. A proposed model can be recommended which will be helpful for enhancing community's participation in tourism as well as making Community Based Tourism (CBT) successful in Sylhet.

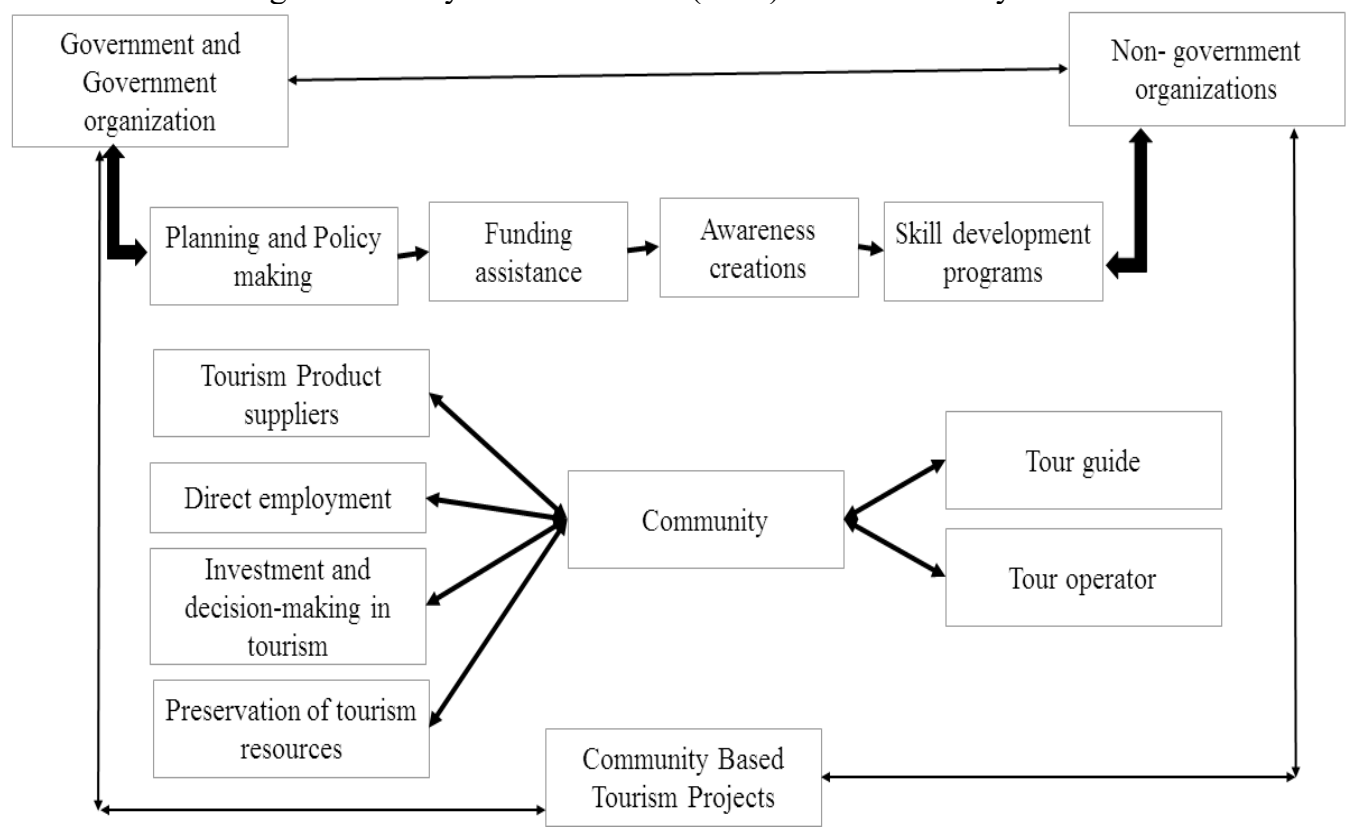

The above model is proposed as a guide for the Community to participate in tourism and to achieve economic, socio-cultural and environmental sustainability and self-reliance. Through participation, the communities can 
make wise decisions to mitigate the negative impacts of tourism and have the opportunity of controlling over tourism in their community.

\section{Concluding remarks:}

Tourism is typically regarded as an effective tool for boosting economic growth, particularly in developing countries. Community Based Tourism has been perceived as an effective instrument for poverty alleviation and reduction by many development organizations. CBT provides many gains to local people. Community development through CBT provides economic benefits that are distributed widely and equitably, while remaining in the hands of locals rather than outsiders. CBT has provided a variety of tourism-related jobs for the villagers to earn extra income in addition to their main sources. Environmental conservation and cultural conservation can also be achieved through Community Based Tourism development. Summing up the research result can be said that communities in Sylhet have enormous potential of unused resources and opportunities for Community Based Tourism (CBT) development. Researcher identify from field observation that there are various factors for which the communities are less interested in tourism. These are the unawareness of communities, poor benefit and profit sharing opportunities, poor decision making opportunities and lack of enough knowledge, skill and unawareness on tourism, negative perception on tourism, deprived from the benefits of tourism industry, insufficient fund for investing and so on. Proper training, knowledge enlighten and skill development programs on tourism industry, awareness creation among locals, direct involvement in planning, financial supports will help to increase their direct participation in tourism industry. So, it can be said that Community Based Tourism (CBT) could be one of the most successful concept for the conservation of all types of resources as well as destination by enhancing the participation of local community and community participation could be increased by following the above recommendations.

\section{Reference}

APEC Secretariat (2010), APEC Publication number: 210-TC-03.2. APEC Tourism Working Group (2010) "Effective Community Based Tourism : A Best Practice Manual; Asia-Pacific Economic Co-operation: Sydney, Australia."

Ashley, C, and D.Roe (1998) "Enhancing Community Involvement in Wildlife Tourism: Issues and Challenges." "IIED Wildlife and Development Series No. 11,London : International Institute for Environment and Development.

Blackstock,K (2005) “A Critical look at community based tourism”. Community development journal, Vol 40 No 1 .

Choi, H.C and Sirakaya E (2005) "Measuring Residents' Attitude toward Sustainable Tourism: Development of Sustainable Tourism Attitude Scale, Journal of Travel Research 43(4): 380-394.

Dodds, R (2007) "Sustainable Tourism and Policy Implementation: Lessons from the Case of Calvia, Spain." Current issues in tourism.

Dwyer L, Petter Forsyth, John Madden and Ray Spurr(2010) “Economic Impacts of Inbound Tourism under different Assumptions Regarding the Macro economy" published in Journal of current issues in tourism, Volum -3,2000, Issue 4

Elena, M, Lee, M.H, Suhartono, H, Hossein ,I Rahman, N.H.A and Bazilah , N.A (2012), “Fuzzy time series and sarima Model for forecasting tourist arrivals to Bali." Journal teknologi.

Hall, C. M (1994), "Tourism and policies,power and place" Chichester: wilwy.

Haywood, K M (1988) "Responsible and responsive tourism planning in the community" Tourism Management 9(2)

Jackson, S. L (2009) "Research Methods and Statistics: A critical thinking Approach $3^{\text {rd }}$ edition, Belmont, CA: Wadsworth.

Pearce, D. G (1992) “Alternative Tourism: concepts, classification and questions. In V. L. Smith and W. R. Eadington," Tourism alternatives: potentials and problems in the development of tourism, USA: International Academy for the Study of Tourism.

P.A Johnson (2010) "Realizing Rural Community Based Tourism Development : Prospects for Social-Economy Enterprises, Journal of Rural and community development, ISSN: 1712-8277.

Khanal, B. R and Babar , J. T (2007) "Community Based Ecotourism for Sustainable Development in the Mekong Region, Swiss Agency for Development and Co-operation, Hanoi resource center, Saradindu Shekhar Chakma, Ethnic cleansing in Chittagong Hill Tracts.

Murphy, Peter E (1985) Tourism : A community Approach. London : University Press. Murphy P (1988) Community driven tourism planning, Tourism Management, 9(2), 96-104. Murphy, P E (2012). Tourism: A community Approaches (4 ${ }^{\text {th }}$ edition). New York, NY: Routledge

Nunkoo, R; Smith D.L ; Ramkissoon H. Residents' attitudes to tourism: A longitudinal study of 140 articles from 1984 to 2010. J Sustain Tour, 2013. 
Ried D G (2003), Tourism, Globalization and Development: Responsible Tourism Planning. London: Pluto.

Simpson, P. M \& siguaw, J A (2008), "Perceived travel risks: The traveler perspective and manage ability. International Journal of Tourism Research, 10,315-327

Timothy B (1999). Participatory Planning: A view of tourism in Indonesia . Annals of Tourism Research.

Timothy, D. J (2002) Tourism and community development issues. In Sharpley R and D Telfer. Tourism and development : concepts and issues, 149-164, Channel view publications Clevedon.

Tosun C (2000), "Limits to community partcicipation in the tourism development process in developing countries,tourism management, Volum 21, 613-633.

World Travel and Tourism Council (2014). Travel and Tourism Economic Impact 2014: World.

World wide fund for Nature international (2001), Guidelines for community based ecotourism Development, Ludbury, UK.

A. Author:

Birthplace: Gazipur City, Dhaka, Bangladesh.

Educational qualification:

\begin{tabular}{|l|l|l|l|l|l|}
\hline Year & Degree & Major & Institution & City & Country \\
\hline 2019 & MBA & $\begin{array}{l}\text { Tourism and Hospitality } \\
\text { Management }\end{array}$ & University of Dhaka & Dhaka city & Bangladesh \\
\hline 2017 & BBA & $\begin{array}{l}\text { Tourism and Hospitality } \\
\text { Management }\end{array}$ & University of Dhaka & Dhaka city & Bangladesh \\
\hline 2012 & HSC & Business Studies & $\begin{array}{l}\text { Gazipur Government Women' } \\
\text { College }\end{array}$ & Gazipur City & Bangladesh \\
\hline 2010 & SSC & Business Studies & Harinal High School & Gazipur City & Bangladesh \\
\hline
\end{tabular}

